\author{
Krzysztof CHMIELOWSKI ${ }^{1}$ \\ Bernadeta RAJCHEL ${ }^{2}$ \\ Magdalena KARNAS ${ }^{3}$
}

\title{
ANALIZA SKUTECZNOŚCI DZIAŁANIA OCZYSZCZALNI ŚCIEKÓW ,KUJAWY”
}

\begin{abstract}
W pracy przedstawiono analizę skuteczności działania oczyszczalni ścieków „Kujawy”. Jest to mechaniczno-biologiczna oczyszczalnia ścieków z podwyższonym usuwaniem biogenów. Obiekt został zaprojektowany na 251818 RLM i na przepływ średniodobowy wynoszący $80000 \mathrm{~m} 3 \cdot \mathrm{d}^{-1}$. W procesie biologicznym wykorzystywany jest trójfazowy reaktor biologiczny, w którym jest prowadzony proces niskoobciążonego osadu czynnego technologią Bardenpho (zmodyfikowaną). Badaniami objęto okres od stycznia 2009 roku do listopada 2014 roku. Analizie poddano następujące wskaźniki zanieczyszczeń: $\mathrm{BZT}_{5}, \mathrm{ChZT}_{\mathrm{Cr}}$, zawiesina ogólna, Nog., Pog.. Uwzględniając wartości poszczególnych wskaźników obliczono stopień redukcji zanieczyszczeń. Dodatkowo obliczono współczynnik niezawodności oczyszczalni dla analizowanych wskaźników zanieczyszczeń. W pracy obliczono podstawowe statystyki opisowe dotyczące wartości badanych wskaźników w ściekach surowych, oczyszczonych oraz ich redukcji. Na podstawie zebranego i przeanalizowanego materiału należy stwierdzić, że oczyszczalnia ścieków „Kujawy” pod względem zmniejszania podstawowych wskaźników zanieczyszczenia ścieków działa poprawnie, natomiast należy zwiększyć skuteczność usuwania azotu ogólnego.
\end{abstract}

Słowa kluczowe: ścieki bytowe, oczyszczalnia, skuteczność oczyszczania, redukcja

\section{Wprowadzenie}

Oczyszczanie ścieków bytowych jest ważnym zagadnieniem dotyczącym większości aglomeracji. Nieoczyszczone ścieki powodują degradację środowiska naturalnego i stanowią poważny problem. Istnieją trzy podstawowe metody oczyszczania ścieków, jak: mechaniczna, biologiczna i chemiczna. W metodzie biologicznej najczęściej wykorzystywany jest osad czynny. Osad czynny to kolonie mikroorganizmów tworzące cząstki o średnicy $50 \div 100 \mu \mathrm{m}$. W zależności

\footnotetext{
${ }^{1}$ Autor do korespondencji/corresponding author: Krzysztof Chmielowski, Uniwersytet Rolniczy w Krakowie, Wydział Inżynierii Środowiska i Geodezji, Katedra Inżynierii Sanitarnej i Gospodarki Wodnej, Al. Mickiewicza 24/28, 30-059 Kraków, tel. 12 6624187, k.chmielowski@ur.krakow.pl

${ }^{2}$ Bernadeta Rajchel, Państwowa Wyższa Szkoła Zawodowa w Krośnie

${ }^{3}$ Magdalena Karnas, absolwentka Uniwersytetu Rolniczego w Krakowie
} 
od zróżnicowania stopnia obciążenia następuje zmiana różnorodności gatunków w komorze osadu czynnego [1]. Głównymi składnikami usuwanymi ze ścieków są związki węgla, fosforu, azotu oraz zawiesina ogólna. Przykładem obiektu usuwającego ze ścieków wymienione związki jest oczyszczalnia ścieków „Kujawy" zlokalizowana w Krakowie, w województwie małopolskim. Wymagane wartości poszczególnych wskaźników zanieczyszczenia ścieków na odpływie z oczyszczalni do odbiornika, zostały określone przez Rozporządzenie [7] oraz pozwolenie wodno-prawne [6].

\section{Cel pracy i metodyka badań}

Celem pracy jest analiza skuteczności działania oczyszczalni ścieków „,Kujawy". Badaniami objęto okres od stycznia 2009 roku do listopada 2014 roku. Analizie poddano następujące wskaźniki zanieczyszczeń: $\mathrm{BZT}_{5}, \mathrm{ChZT}_{\mathrm{Cr}}$, zawiesina ogólna, $\mathrm{N}_{\mathrm{og}}$, $\mathrm{P}_{\mathrm{og}}$. Próbki ścieków do analiz pobierano zgodnie $\mathrm{z}$ ustalonymi normami (PN-74/C-04620/00, PN-EN 25667-2: 1999). W sumie w latach 20092014 przeprowadzono ponad tysiąc serii analiz fizykochemicznych, podczas których zbadano ponad dwa tysiące próbek ścieków. Analizy prób ścieków wykonano zgodnie $\mathrm{z}$ obowiązującymi normami (PN-EN 1899-2:2002, PN-ISO 15705:2005, PN-EN 872:2007, PN-EN 11905-1:2001, PN-EN ISO 156812:2006). Metody oznaczania badanych wskaźników były następujące: $\mathrm{BZT}_{5}$ metoda manometryczna, $\mathrm{ChZT}_{\mathrm{Cr}}$ - metoda dwuchromianowa, zawiesina ogólna metoda wagowa bezpośrednia, azot ogólny - z użyciem spektrofotometru, fosfor ogólny - z użyciem spektrofotometru. Analizy fizykochemiczne wykonane były przez laboratorium oczyszczalni ścieków „Kujawy” oraz przez Centralne laboratorium w oczyszczalni w Płaszowie.

Uwzględniając wartości poszczególnych wskaźników obliczono stopień redukcji zanieczyszczeń.

$$
\eta=\frac{S_{p}-S_{k}}{S_{p}} \cdot 100[\%]
$$

gdzie $S_{\mathrm{p}}$ - wartość wskaźnika w ściekach surowych $\left[\mathrm{mg} \cdot \mathrm{dm}^{-3}\right]$,

$\mathrm{S}_{\mathrm{k}}$ - wartość wskaźnika w ściekach oczyszczonych $\left[\mathrm{mg} \cdot \mathrm{dm}^{-3}\right]$.

\section{Charakterystyka obiektu badań}

Oczyszczalnia ścieków „Kujawy” znajduje się w południowo-wschodniej części miasta Krakowa. Obiekt został zaprojektowany na 251818 RLM i na przepływ średniodobowy wynoszący $80000 \mathrm{~m}^{3} \cdot \mathrm{d}^{-1}$. „Kujawy” to oczyszczalnia mechaniczno-biologiczna, z podwyższonym usuwaniem związków azotu i fosforu oraz wspomaganiem chemicznym w zakresie eliminacji fosforu ze ścieków przy użyciu siarczanu żelaza. W procesie biologicznym wykorzystywany jest trójfazowy reaktor biologiczny, w którym jest prowadzony proces niskoobciążonego osadu czynnego technologią Bardenpho (zmodyfikowaną). Proces prowa- 
dzi się przy stosowaniu recyrkulacji wewnętrznej i zewnętrznej. Podczas zewnętrznej recyrkulacji wprowadzono predenitryfikację osadu recyrkulowanego, który ma na celu odtlenienie recyrkulowanego osadu i usunięcie zawartych w tym osadzie azotanów. Tlen, który jest niezbędny podczas oczyszczania biologicznego dostarczony zostaje za pomocą urządzeń napowietrzających w części tlenowej komór. Zgodnie z pozwoleniem wodno-prawnym [6] dopuszczalne stężenie zanieczyszczeń $\mathrm{w}$ oczyszczonych ściekach nie powinno przekroczyć następujących wartości: $\mathrm{BZT}_{5}-15 \mathrm{mgO}_{2} \cdot \mathrm{dm}^{-3}, \mathrm{ChZT}_{\mathrm{Cr}}-125 \mathrm{mgO} \cdot \mathrm{dm}^{-3}$, zawiesina ogólna - $35 \mathrm{mg} \cdot \mathrm{dm}^{-3}$, azot ogólny - 22,5 $\mathrm{mgN}_{\mathrm{og}} \cdot \mathrm{dm}^{-3}$, fosfor ogólny $-1,5 \mathrm{mgP} \mathrm{og}_{\mathrm{g}} \cdot \mathrm{dm}^{-3}$. Poniżej na rycinie 1 przedstawiono uproszczony schemat blokowy przepływu ścieków przez główne obiekty na oczyszczalni ścieków „Kujawy”.

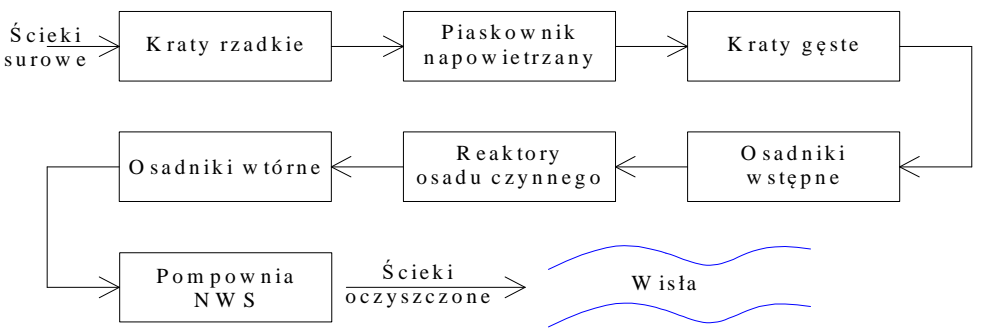

Rys. 1. Schemat technologiczny oczyszczalni ścieków „Kujawy”

Fig. 1. Technological flow sheet of the "Kujawy" sewage treatment plant

\section{Wyniki badań i dyskusja}

W tabeli 1 przedstawiono wyniki badań dotyczące wartości analizowanych wskaźników zanieczyszczenia w ściekach surowych.

Tabela 1. Podstawowe charakterystyki zanieczyszczeń zawartych w ściekach surowych dopływających do oczyszczalni ścieków „Kujawy”

Table 1. Basic characteristics of pollutants contained in raw sewage flowing into the "Kujawy" sewage treatment plant

\begin{tabular}{|c|c|c|c|c|c|c|}
\hline Parametr & Jednostka & $\mathbf{B Z T}_{\mathbf{5}}$ & $\mathbf{C h Z T}_{\mathbf{C r}}$ & $\begin{array}{c}\text { Zawiesina } \\
\text { ogólna }\end{array}$ & $\mathbf{N}_{\mathbf{o g}}$ & $\mathbf{P}_{\mathbf{o g}}$ \\
\hline Liczba próbek & $\mathrm{szt}$. & 1009 & 1008 & 1009 & 1007 & 1003 \\
\hline Średnia & $\mathrm{mg} \cdot \mathrm{dm}^{-3}$ & 305,77 & 670,11 & 277,98 & 74,10 & 7,19 \\
\hline Minimum & $\mathrm{mg} \cdot \mathrm{dm}^{-3}$ & 33,00 & 81,00 & 54,00 & 9,80 & 0,71 \\
\hline Maksimum & $\mathrm{mg} \cdot \mathrm{dm}^{-3}$ & 1100,00 & 2286,00 & 1000,00 & 195,00 & 20,90 \\
\hline Mediana & $\mathrm{mg} \cdot \mathrm{dm}^{-3}$ & 300,00 & 667,50 & 270,00 & 71,60 & 7,23 \\
\hline Rozstęp & $\mathrm{mg} \cdot \mathrm{dm}^{-3}$ & 1067,00 & 2205,00 & 946,00 & 185,20 & 20,19 \\
\hline $\begin{array}{c}\text { Odchylenie } \\
\text { standardowe }\end{array}$ & $\mathrm{mg} \cdot \mathrm{dm}^{-3}$ & 103,06 & 222,25 & 112,09 & 20,14 & 1,71 \\
\hline $\begin{array}{c}\text { Współczynnik } \\
\text { zmienności }\end{array}$ & $\%$ & 33,71 & 33,17 & 40,32 & 27,17 & 23,79 \\
\hline
\end{tabular}


Na podstawie danych zawartych w tabeli 1 stwierdzono, że wartość $\mathrm{BZT}_{5}$ ścieków surowych wynosiła od 33,00 do $1100,00 \mathrm{mgO}_{2} \cdot \mathrm{dm}^{-3}$, przy wartości średniej wynoszącej $305,77 \mathrm{mgO}_{2} \cdot \mathrm{dm}^{-3}$. Podobne wyniki przedstawiają inni autorzy $[5,8,9,10]$. Według Hartmanna [4] wartość tego wskaźnika dla ścieków komunalnych wynosi ponad $200 \mathrm{mgO}_{2} \cdot \mathrm{dm}^{-3}$. Wartość $\mathrm{ChZT}_{\mathrm{Cr}} \mathrm{w}$ ściekach surowych wahała się w przedziale od 81,00 do $2286,00 \mathrm{mgO}_{2} \cdot \mathrm{dm}^{-3}$. Średnia wartość tego wskaźnika w badanym wieloleciu wyniosła $670,11 \mathrm{mgO}_{2} \cdot \mathrm{dm}^{-3}$. Wartości dla ChZT $\mathrm{Cr}_{\mathrm{r}}$ dla ścieków komunalnych wynoszą poniżej $600 \mathrm{mg} \cdot \mathrm{dm}^{-3}$, w ściekach przemysłowych mogą wzrosnąć do kilku tysięcy [4]. Stężenie zawiesiny ogólnej w ściekach dopływających do oczyszczalni wahało się w przedziale od 54,00 do $1000,00 \mathrm{mg} \cdot \mathrm{dm}^{-3}$, przy wartości średniej wynoszącej $277,98 \mathrm{mg} \cdot \mathrm{dm}^{-3}$. Zawartość azotu ogólnego w ściekach surowych wynosiła od 9,80 do 195,00 $\mathrm{mgN}_{\mathrm{og}} \cdot \mathrm{dm}^{-3}$, a fosforu ogólnego od 0,71 do $20,90 \mathrm{mgP}_{\mathrm{og}} \cdot \mathrm{dm}^{-3}$. Średnia zawartość azotu ogólnego wynosiła $74,10 \mathrm{mgP} \mathrm{og} \cdot \mathrm{dm}^{-3}$, a fosforu $7,19 \mathrm{mgP} \mathrm{og} \cdot \mathrm{dm}^{-3}$. Ścieki surowe charakteryzowały się wysokimi wartościami rozstępu wynoszącymi dla $\mathrm{BZT}_{5}-1067 \mathrm{mg} \cdot \mathrm{dm}^{-3}, \mathrm{ChZT}_{\mathrm{Cr}}-2205,00 \mathrm{mg} \cdot \mathrm{dm}^{-3}$, zawiesina ogólna $946,00 \mathrm{mg} \cdot \mathrm{dm}^{-3}$.

Tabela 2. Podstawowe charakterystyki zanieczyszczeń zawartych w ściekach odpływających z oczyszczalni ścieków „Kujawy”

Table 2. Basic characteristics of pollutants contained in sewage flowing out of the "Kujawy" sewage treatment plant

\begin{tabular}{|c|c|c|c|c|c|c|}
\hline Parametr & Jednostka & $\mathbf{B Z T}_{\mathbf{5}}$ & $\mathbf{C h Z T}_{\mathbf{C r}}$ & Zawiesina ogólna & $\mathbf{N}_{\mathbf{o g}}$ & $\mathbf{P}_{\mathbf{o g}}$ \\
\hline Liczba próbek & $\mathrm{szt}$ & 1009 & 1009 & 1008 & 1009 & 998 \\
\hline Średnia & $\mathrm{mg} \cdot \mathrm{dm}^{-3}$ & 4,02 & 28,71 & 6,09 & 21,84 & 0,42 \\
\hline Minimum & $\mathrm{mg} \cdot \mathrm{dm}^{-3}$ & 1,00 & 4,10 & 0,30 & 3,97 & 0,08 \\
\hline Maksimum & $\mathrm{mg} \cdot \mathrm{dm}^{-3}$ & 22,00 & 89,00 & 33,00 & 107,00 & 2,78 \\
\hline Mediana & $\mathrm{mg} \cdot \mathrm{dm}^{-3}$ & 3,30 & 27,60 & 5,00 & 17,10 & 0,35 \\
\hline Rozstęp & $\mathrm{mg} \cdot \mathrm{dm}^{-3}$ & 21,00 & 84,90 & 32,70 & 103,03 & 2,78 \\
\hline $\begin{array}{c}\text { Odchylenie } \\
\text { standardowe }\end{array}$ & $\mathrm{mg} \cdot \mathrm{dm}^{-3}$ & 2,46 & 9,15 & 4,09 & 15,67 & 0,26 \\
\hline $\begin{array}{c}\text { Współczynnik } \\
\text { zmienności }\end{array}$ & $\%$ & 61,23 & 31,86 & 67,04 & 71,77 & 63,14 \\
\hline
\end{tabular}

Na podstawie danych zawartych w tabeli 2 stwierdzono, że wartość $\mathrm{BZT}_{5}$ w ściekach oczyszczonych kształtowała się na poziomie od 1,00 do $22,00 \mathrm{mgO} \cdot \mathrm{dm}^{-3}$, a wartość średnia wyniosła $4,02 \mathrm{mgO}_{2} \cdot \mathrm{dm}^{-3}$. Mediana tego wskaźnika wyniosła $3,30 \mathrm{mgO}_{2} \cdot \mathrm{dm}^{-3}$. Wartość $\mathrm{ChZT}_{\mathrm{Cr}} \mathrm{W}$ ściekach wahała się od 4,10 do $89,00 \mathrm{mgO}_{2} \cdot \mathrm{dm}^{-3}$, a średnio wynosiła $-28,71 \mathrm{mgO}_{2} \cdot \mathrm{dm}^{-3}$. Średnie stężenie zawiesiny ogólnej wynosiło 6,09 , wartość minimalna - 0,30, a maksymalna - 33,00 $\mathrm{mg} \cdot \mathrm{dm}^{-3}$. Wartość azotu ogólnego kształtowała się na poziomie od 3,97 do $107,00 \mathrm{mg} \cdot \mathrm{dm}^{-3}$. Zawartość fosforu ogólnego w ściekach oczyszczonych wynosiła od 0,08 do 2,78 , przy wartości średniej na poziomie $0,42 \mathrm{mg} \cdot \mathrm{dm}^{-3}$. 
Na rysunkach 2-6 przedstawiono wyniki dotyczące ścieków surowych i oczyszczonych dla analizowanych wskaźników. W tabeli 3 przedstawiono stopień redukcji wraz z współczynnikiem niezawodności.

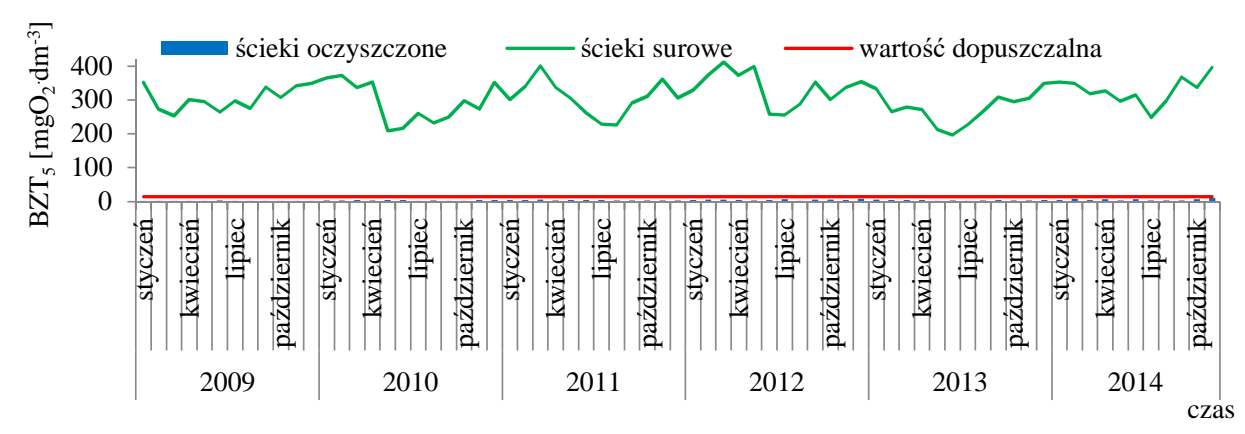

Rys. 2. Średnie miesięczne wartości BZT 5 ścieków surowych i oczyszczonych

Fig. 2. Average monthly values of $\mathrm{BOD}_{5}$ for raw and treated sewage

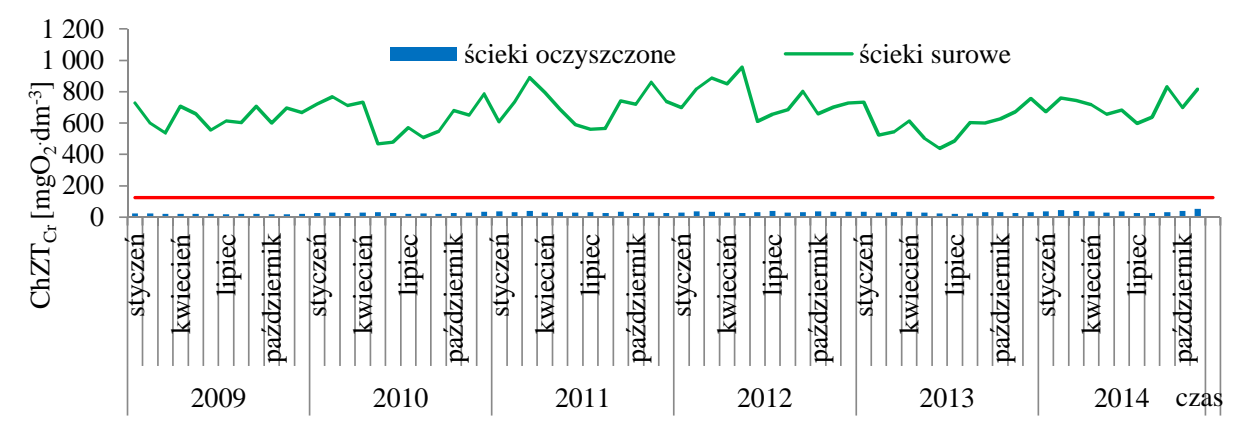

Rys. 3. Średnie miesięczne wartości $\mathrm{ChZT}_{\mathrm{Cr}}$ ścieków surowych i oczyszczonych

Fig. 3. Average monthly values of $\mathrm{COD}_{\mathrm{Cr}}$ for raw and treated sewage

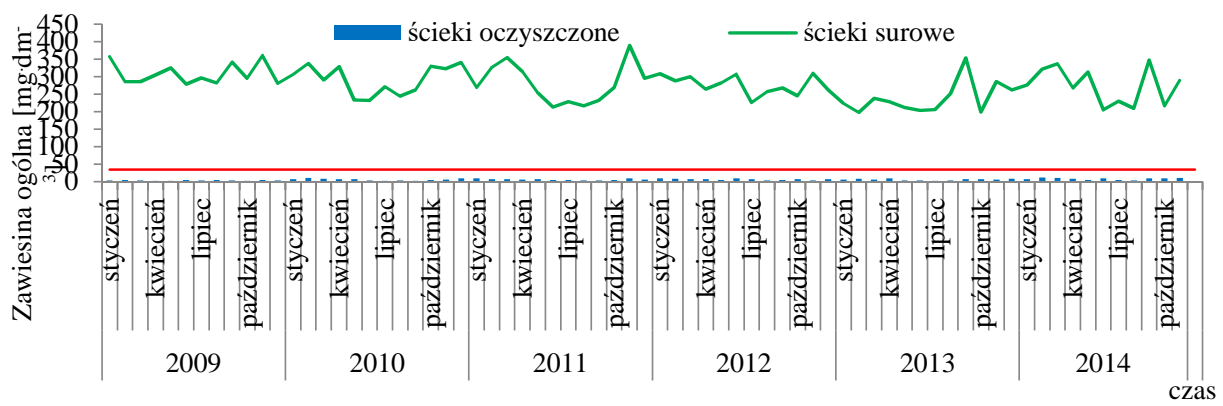

Rys. 4. Średnie miesięczne wartości zawiesiny ogólnej w ściekach surowych i oczyszczonych

Fig. 4. Average monthly values of total suspended solids for raw and treated sewage 


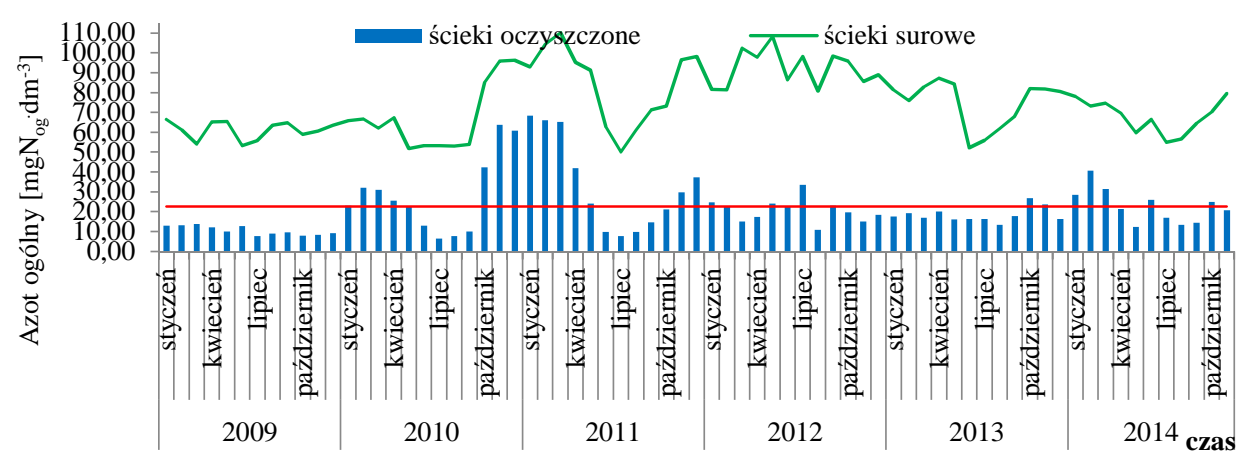

Rys. 5. Średnie miesięczne wartości azotu ogólnego w ściekach surowych i oczyszczonych

Fig. 5. Average monthly values of total nitrogen for raw and treated sewage

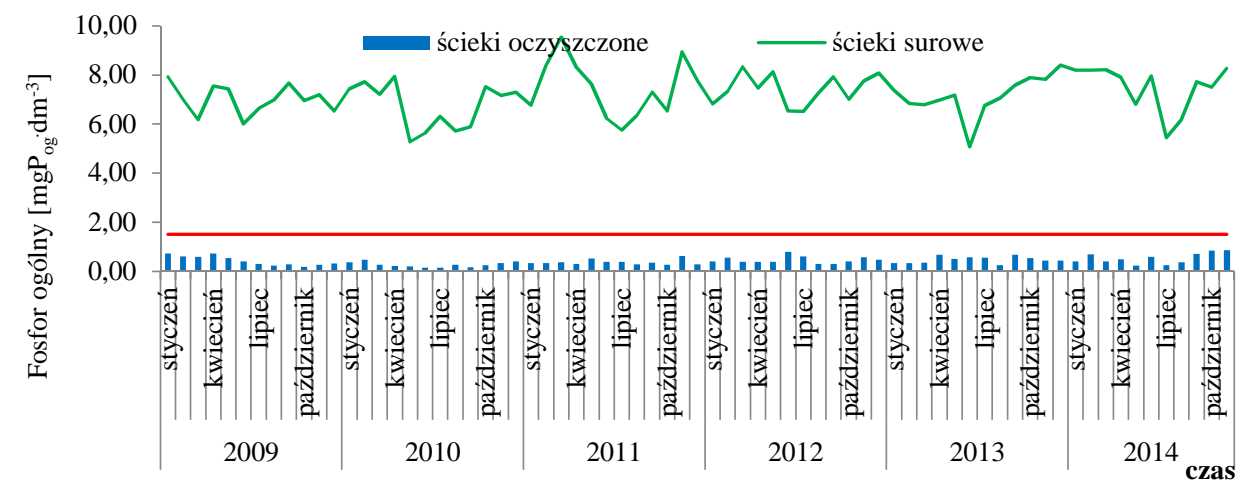

Rys. 6. Średnie miesięczne wartości fosforu ogólnego w ściekach surowych i oczyszczonych

Fig. 6. Average monthly values of total phosphorus for raw and treated sewage

Maksymalna dopuszczalna wartość wskaźnika $\mathrm{BZT}_{5} \mathrm{w}$ ściekach oczyszczonych wynosi $15 \mathrm{mgO}_{2} \cdot \mathrm{dm}^{-3} \mathrm{i}$ zgodnie $\mathrm{z}$ rysunkiem 2 nie zaobserwowano przekroczeń tego wskaźnika. W przypadku wskaźnika $\mathrm{ChZT}_{\mathrm{Cr}}$ dopuszczalny jego poziom wynosi $125 \mathrm{mgO}_{2} \cdot \mathrm{dm}^{-3}$ i również nie został przekroczony w analizowanym okresie (rysunek 3). Dla zawiesiny ogólnej dopuszczalne stężenie w ściekach oczyszczonych wynosi $35 \mathrm{mg} \cdot \mathrm{dm}^{-3}$ i zgodnie z rysunkiem 4 nie zaobserwowano przekroczeń tej wartości. Sytuacja jest odmienna w przypadku azotu ogólnego w ściekach oczyszczonych. Na rysunku 5 widać wielokrotne przekroczenia wartości tego wskaźnika w ściekach oczyszczonych wynoszącej $22,5 \mathrm{mgN}_{\mathrm{og}} \cdot \mathrm{dm}^{-3}$. W stosunku do wartości średnich miesięcznych stwierdzono 28 przekroczeń azotu ogólnego w stosunku wartości dopuszczalnej, co stanowi 39,44\% wartości. Zaobserwowane wysokie stężenia azotu ogólnego w ściekach surowych (zwłaszcza w okresie od października 2010 do kwietnia 2011) mogły się przyczynić do wystąpienia podwyższonych wartości tego wskaźnika w ście- 
kach oczyszczonych. Przyczyną wysokich stężeń azotu ogólnego w ściekach surowych mogły być ścieki dowożone taborem asenizacyjnym. Dla fosforu ogólnego wartość dopuszczalna w ściekach oczyszczonych wynosi $1,5 \mathrm{mgP}_{\mathrm{og}} \cdot \mathrm{dm}^{-3} \mathrm{i}$ jak widać na rysunku $6 \mathrm{w}$ analizowanym okresie nie wystąpiło przekroczenie tej wartości. W tabeli 3 zestawiono stopień redukcji badanych wskaźników dla okresu badawczego od 2009 do 2014 roku.

Tabela 3. Analiza pracy oczyszczalni ścieków „Kujawy” w latach 2009-2014

Table 3. Analysis of operation of the "Kujawy" sewage treatment plant in the period of 2009-2014

\begin{tabular}{|c|c|c|c|c|}
\hline \multirow{2}{*}{ Wskaźnik } & \multirow{2}{*}{$\begin{array}{c}\text { Wymagany } \\
\text { stopień redukcji }\end{array}$} & \multicolumn{3}{|c|}{ Stopień redukcji [\%] } \\
\cline { 3 - 5 } & & $\begin{array}{c}\text { Wartość } \\
\text { średnia }\end{array}$ & $\begin{array}{c}\text { Wartość } \\
\text { minimalna }\end{array}$ & $\begin{array}{c}\text { Wartość } \\
\text { maksymalna }\end{array}$ \\
\hline $\mathrm{BZT}_{5}$ & 90 & 98,56 & 91,82 & 99,77 \\
\hline ChZT $_{\mathrm{Cr}}$ & 75 & 95,25 & 64,20 & 99,45 \\
\hline zawiesina ogólna & 90 & 97,45 & 80,67 & 99,70 \\
\hline azot ogólny & 85 & 70,69 & --- & 92,86 \\
\hline fosfor ogólny & 90 & 93,93 & 59,46 & 100,00 \\
\hline
\end{tabular}

Interpretując dane z tabeli 3 można stwierdzić, że oczyszczalnia ścieków „Kujawy” osiągnęła wymagany stopień redukcji zanieczyszczeń określany przez następujące wskaźniki: $\mathrm{BZT}_{5}, \mathrm{ChZT}_{\mathrm{Cr}}$, zawiesinę ogólną oraz fosfor ogólny. Jedynie średnia redukcja azotu ogólnego przyjęła wartość mniejszą niż określona w pozwoleniu wodno-prawnym. Analizując wartości redukcji badanych wskaźników zanieczyszczenia ścieków należy stwierdzić, że są one wyższe niż te podawane w innych publikacjach $[9,10]$ (za wyjątkiem azotu ogólnego).

$\mathrm{W}$ dalszej części w tabeli 4 przedstawiono stopień redukcji $\mathrm{BZT}_{5} \mathrm{w}$ latach 2009-2014.

Tabela 4. Stopień redukcji BZT 5 w latach 2009-2014 w oczyszczalni ścieków „Kujawy”

Table 4. Degree of $\mathrm{BOD}_{5}$ reduction in the period of 2009-2014 in the "Kujawy" sewage treatment plant

\begin{tabular}{|c|c|c|c|c|c|c|}
\hline \multirow[b]{2}{*}{ Lp. } & \multirow[b]{2}{*}{ Rok } & \multirow[b]{2}{*}{ Jednostka } & \multicolumn{3}{|c|}{ Stopień redukcji $\mathrm{BZT}_{5}$} & \multirow{2}{*}{$\begin{array}{l}\text { Odchylenie } \\
\text { standardowe }\end{array}$} \\
\hline & & & $\begin{array}{l}\text { Wartość } \\
\text { średnia }\end{array}$ & $\begin{array}{c}\text { Wartość } \\
\text { minimalna }\end{array}$ & $\begin{array}{c}\text { Wartość } \\
\text { maksymalna }\end{array}$ & \\
\hline 1. & 2009 & \multirow{6}{*}{$\%$} & 99,15 & 96,57 & 99,76 & 0,47 \\
\hline 2. & 2010 & & 98,72 & 93,48 & 99,72 & 0,96 \\
\hline 3. & 2011 & & 98,54 & 94,53 & 99,62 & 0,79 \\
\hline 4. & 2012 & & 98,46 & 92,17 & 99,61 & 1,00 \\
\hline 5. & 2013 & & 98,33 & 94,73 & 99,70 & 0,95 \\
\hline 6. & 2014 & & 98,07 & 91,82 & 99,77 & 1,27 \\
\hline
\end{tabular}


Analizując dane przedstawione w tabeli 4 można zauważyć, że w latach 2009-2014 skuteczność zmniejszenia BZT $_{5}$ była na wysokim poziomie. Średnia wartość zmniejszenia BZT $_{5}$ w roku 2009 wyniosła 99,15\% i była najwyższa w badanych latach. W pozostałych latach za każdym razem przekroczyła $98 \%$. Należy stwierdzić, że jest to wysoka redukcja i świadczy o poprawnej pracy oczyszczalni. Na uwagę zasługują niskie wartości odchylenia standardowego w poszczególnych latach (od 0,47 w roku 2009 do 1,27 w roku 2014). Niskie wartości odchylenia standardowego świadczą o stabilności zachodzących procesów i ustabilizowanej redukcji wskaźnika $\mathrm{BZT}_{5}$.

Kolejnym analizowanym wskaźnikiem było $\mathrm{ChZT}_{\mathrm{Cr}}$. Dokonano analizy redukcji tego wskaźnika w rozbiciu na lata 2009-2014. W tabeli 5 przedstawiono stopień redukcji ChZT $\mathrm{Cr}_{\mathrm{w}}$ latach 2009-2014 w oczyszczalni ścieków „Kujawy”.

Tabela 5. Stopień redukcji ChZT $\mathrm{Cr}_{\mathrm{W}}$ w latach 2009-2014 w oczyszczalni ścieków „Kujawy”

Table 5. Degree of $\mathrm{COD}_{\mathrm{Cr}}$ reduction in the period of 2009-2014 in the "Kujawy" sewage treatment plant

\begin{tabular}{|c|c|c|c|c|c|c|}
\hline \multirow[b]{2}{*}{ Lp. } & \multirow[b]{2}{*}{ Rok } & \multirow[b]{2}{*}{ Jednostka } & \multicolumn{3}{|c|}{${\text { Stopień redukcji } \mathrm{ChZT}_{\mathrm{Cr}}}$} & \multirow{2}{*}{$\begin{array}{l}\text { Odchylenie } \\
\text { standardowe }\end{array}$} \\
\hline & & & $\begin{array}{c}\text { Wartość } \\
\text { średnia }\end{array}$ & $\begin{array}{c}\text { Wartość } \\
\text { minimalna }\end{array}$ & $\begin{array}{c}\text { Wartość } \\
\text { maksymalna }\end{array}$ & \\
\hline 1. & 2009 & \multirow{6}{*}{$\%$} & 96,49 & 90,33 & 98,97 & 1,35 \\
\hline 2. & 2010 & & 95,43 & 85,05 & 99,45 & 1,97 \\
\hline 3. & 2011 & & 95,22 & 84,38 & 98,47 & 1,87 \\
\hline 4. & 2012 & & 95,28 & 84,67 & 98,32 & 2,12 \\
\hline 5. & 2013 & & 94,56 & 84,70 & 98,27 & 2,47 \\
\hline 6. & 2014 & & 94,21 & 64,20 & 98,75 & 3,62 \\
\hline
\end{tabular}

Biorąc pod uwagę dane przedstawione w tabeli 5 można zauważyć, że w latach 2009-2014 skuteczność zmniejszenia ChZT $_{\mathrm{Cr}}$ była na niższym poziomie niż redukcja $\mathrm{BZT}_{5}$. Średnia wartość zmniejszenia $\mathrm{ChZT}_{\mathrm{Cr}} \mathrm{w}$ roku 2009 wyniosła $96,49 \%$ i była najwyższa w badanych latach. W pozostałych latach za każdym razem przekroczyła $94 \%$. Biorąc powyższe pod uwagę należy stwierdzić, że jest to wysoka redukcja i świadczy o poprawnej pracy oczyszczalni. Podobnie jak w przypadku BZT $_{5}$ na uwagę zasługują niskie wartości odchylenia standardowego $\mathrm{ChZT}_{\mathrm{Cr}} \mathrm{w}$ poszczególnych latach (od $1,35 \%$ w roku 2009 do 3,62\% w roku 2014). Niskie wartości odchylenia standardowego świadczą o ustabilizowanej redukcji wskaźnika $\mathrm{ChZT}_{\mathrm{Cr}}$.

Trzecim analizowanym wskaźnikiem z grupy podstawowej była zawiesina ogólna. Dokonano analizy redukcji zawiesiny ogólnej w rozbiciu na poszczególne lata badanego okresu. W tabeli 6 przedstawiono stopień redukcji zawiesiny ogólnej w latach 2009-2014 w oczyszczalni ścieków „Kujawy”.

Poddając analizie dane przedstawione w tabeli 6 można zauważyć, że w latach 2009-2014 skuteczność zmniejszenia zawiesiny ogólnej była na wysokim 
poziomie. Średnia wartość zmniejszenia zawiesiny ogólnej w roku 2009 wyniosła $98,54 \%$ i była najwyższa w badanych latach. W pozostałych latach za każdym razem przekroczyła 97\% za wyjątkiem roku 2014 gdzie średnia skuteczność zmniejszenia wyniosła 96,48\% i była najniższa w badanym okresie. Można stwierdzić, że jest to wysoka redukcja i świadczy o poprawnej pracy oczyszczalni. Podobnie jak w przypadku $\mathrm{BZT}_{5}$ i ChZT $_{\mathrm{Cr}}$ na uwagę zasługują niskie wartości odchylenia standardowego zawiesiny ogólnej w poszczególnych latach (od $1,01 \%$ w roku 2009 do $2,99 \%$ w roku 2014). Niskie wartości odchylenia standardowego świadczą o ustabilizowanej redukcji zawiesiny ogólnej.

W dalszej części przedstawiono skuteczność zmniejszenia wskaźników biogennych (azot ogólny, fosfor ogólny). Dokonano analizy redukcji azotu ogólnego w rozbiciu na poszczególne lata badanego okresu. W tabeli 7 przedstawiono stopień redukcji azotu ogólnego w latach 2009-2014 w oczyszczalni ścieków „Kujawy”.

Tabela 6. Stopień redukcji zawiesiny ogólnej w latach 2009-2014 w oczyszczalni ścieków „Kujawy” Table 6. Degree of total suspended solids reduction in the period of 2009-2014 in the "Kujawy" sewage treatment plant

\begin{tabular}{|c|c|c|c|c|c|c|}
\hline \multirow[b]{2}{*}{ Lp. } & \multirow[b]{2}{*}{ Rok } & \multirow[b]{2}{*}{ Jednostka } & \multicolumn{3}{|c|}{ Stopień redukcji zawiesiny ogólnej } & \multirow[b]{2}{*}{$\begin{array}{l}\text { Odchylenie } \\
\text { standardowe }\end{array}$} \\
\hline & & & $\begin{array}{l}\text { Wartość } \\
\text { średnia }\end{array}$ & $\begin{array}{c}\text { Wartość } \\
\text { minimalna }\end{array}$ & $\begin{array}{c}\text { Wartość } \\
\text { maksymalna }\end{array}$ & \\
\hline 1. & 2009 & \multirow{6}{*}{$\%$} & 98,54 & 92,20 & 99,67 & 1,01 \\
\hline 2. & 2010 & & 97,74 & 86,47 & 99,48 & 1,71 \\
\hline 3. & 2011 & & 97,45 & 87,27 & 99,46 & 1,74 \\
\hline 4. & 2012 & & 97,20 & 87,50 & 99,70 & 2,25 \\
\hline 5. & 2013 & & 97,01 & 90,00 & 99,68 & 1,90 \\
\hline 6. & 2014 & & 96,48 & 80,67 & 99,58 & 2,99 \\
\hline
\end{tabular}

Tabela 7. Stopień redukcji azotu ogólnego w latach 2009-2014 w oczyszczalni ścieków „Kujawy” Table 7. Degree of total nitrogen reduction in the period of 2009-2014 in the "Kujawy" sewage treatment plant

\begin{tabular}{|c|c|c|c|c|c|c|}
\hline \multirow[b]{2}{*}{ Lp. } & \multirow[b]{2}{*}{ Rok } & \multirow[b]{2}{*}{ Jednostka } & \multicolumn{3}{|c|}{ Stopień redukcji $\mathbf{N}_{\mathrm{og}}$} & \multirow{2}{*}{$\begin{array}{c}\text { Odchylenie } \\
\text { standardowe }\end{array}$} \\
\hline & & & $\begin{array}{l}\text { Wartość } \\
\text { średnia }\end{array}$ & $\begin{array}{c}\text { Wartość } \\
\text { minimalna }\end{array}$ & $\begin{array}{c}\text { Wartośćć } \\
\text { maksymalna }\end{array}$ & \\
\hline 1. & 2009 & \multirow{6}{*}{$\%$} & 82,27 & 44,66 & 92,86 & 6,55 \\
\hline 2. & 2010 & & 61,32 & 7,26 & 92,17 & 20,08 \\
\hline 3. & 2011 & & 63,38 & $-46,98$ & 89,93 & 22,42 \\
\hline 4. & 2012 & & 77,33 & 34,75 & 90,00 & 9,57 \\
\hline 5. & 2013 & & 74,46 & 50,00 & 90,34 & 8,12 \\
\hline 6. & 2014 & & 62,64 & $-419,39$ & 91,74 & 43,98 \\
\hline
\end{tabular}


Analizując dane przedstawione w tabeli 7 można zauważyć, że w latach 2009-2014 skuteczność zmniejszenia azotu ogólnego była na średnim poziomie. Wartość redukcji tego wskaźnika określona przez rozporządzenie [7] nie powinna być niższa niż $85 \%$. Średnia wartość zmniejszenia azotu ogólnego w roku 2009 wyniosła $82,27 \%$ i była najwyższa w badanych latach. W pozostałych latach kształtowała się na niższym poziomie (od 61,32\% w roku 2010 do 77,33\% w roku 2012). Można stwierdzić, że jest to niska redukcja i świadczy o okresowo wadliwej pracy oczyszczalni. Potwierdzają to wysokie wartości odchylenia standardowego azotu ogólnego w poszczególnych latach (od 6,55\% w roku 2009 do 43,98\% w roku 2014). Wysokie wartości odchylenia standardowego świadczą o nieustabilizowanej redukcji azotu ogólnego. Powodem tego stanu może być niska temperatura ścieków w okresie zimowym, co może spowalniać procesy nitryfikacji i denitryfikacji w reaktorze biologicznym. Dlatego w przyszłości należy wykonać dodatkowe badania w zakresie odziaływania temperatury ścieków surowych na skuteczność usuwania związków biogennych.

Ostatnim analizowanym wskaźnikiem był fosfor ogólny. Dokonano analizę redukcji fosforu ogólnego w rozbiciu na poszczególne lata badanego okresu. W tabeli 8 przedstawiono stopień redukcji fosforu ogólnego w latach 2009-2014 w oczyszczalni ścieków „Kujawy”.

Tabela 8. Stopień redukcji fosforu ogólnego w latach 2009-2014 w oczyszczalni ścieków „Kujawy”

Table 8. Degree of total phosphorus reduction in the period of 2009-2014 in the "Kujawy" sewage treatment plant

\begin{tabular}{|c|c|c|c|c|c|c|}
\hline \multirow{2}{*}{ Lp. } & \multirow{2}{*}{ Rok } & \multirow{2}{*}{ Jednostka } & \multicolumn{3}{|c|}{ Stopień redukcji $\mathbf{P}_{\mathrm{og}}$} & \multirow{2}{*}{$\begin{array}{c}\text { Odchylenie } \\
\text { standardowe }\end{array}$} \\
\hline & & & $\begin{array}{l}\text { Wartość } \\
\text { średnia }\end{array}$ & $\begin{array}{c}\text { Wartość } \\
\text { minimalna }\end{array}$ & $\begin{array}{c}\text { Wartość } \\
\text { maksymalna }\end{array}$ & \\
\hline 1. & 2009 & \multirow{6}{*}{$\%$} & 93,62 & 71,29 & 98,79 & 3,97 \\
\hline 2. & 2010 & & 95,87 & 73,48 & 98,85 & 3,04 \\
\hline 3. & 2011 & & 94,63 & 69,82 & 99,99 & 3,26 \\
\hline 4. & 2012 & & 93,39 & 59,46 & 97,76 & 4,56 \\
\hline 5. & 2013 & & 93,15 & 72,81 & 98,44 & 3,73 \\
\hline 6. & 2014 & & 92,68 & 63,80 & 98,85 & 5,82 \\
\hline
\end{tabular}

Biorąc pod uwagę dane przedstawione w tabeli 8 można zauważyć, że w latach 2009-2014 skuteczność zmniejszenia fosforu ogólnego była na wysokim poziomie. Wartość redukcji tego wskaźnika określona przez rozporządzenie [7] nie powinna być niższa niż $90 \%$. Średnia wartość zmniejszenia fosforu ogólnego w roku 2010 wyniosła $95,87 \%$ i była najwyższa w badanych latach. W pozostałych latach za każdym razem przekroczyła 93\% za wyjątkiem roku 2014 gdzie średnia skuteczność zmniejszenia fosforu ogólnego wyniosła 92,68\% i była najniższa w badanym okresie. Można stwierdzić, że jest to wysoka redukcja 
i świadczy o poprawnej pracy oczyszczalni. Tak wysoka redukcja fosforu ogólnego wynika z zastosowania odpowiednich środków do strącenia tego pierwiastka w procesie chemicznym. Wartości odchylenia standardowego redukcji fosforu ogólnego w poszczególnych latach kształtowały się od 3,04\% w roku 2010 do $5,82 \%$ w roku 2014.

\section{Podsumowanie i wnioski}

Celem artykułu była analiza skuteczności działania oczyszczalni ścieków „Kujawy”. Badaniami objęto okres od stycznia 2009 roku do listopada 2014 ro$\mathrm{ku}$. Analizie poddano następujące wskaźniki zanieczyszczeń: $\mathrm{BZT}_{5}, \mathrm{ChZT}_{\mathrm{Cr}}$, zawiesina ogólna, $\mathrm{N}_{\text {og. }}, \mathrm{P}_{\text {og. }}$. Przeprowadzona analiza wyników pozwoliła na sformułowanie następujących stwierdzeń i wniosków:

- stwierdzono bardzo wysoką skuteczność zmniejszenia wskaźników zanieczyszczeń ścieków za wyjątkiem azotu ogólnego;

- średni stopień redukcji w badanym okresie dla poszczególnych wskaźników kształtował się następująco: dla $\mathrm{BZT}_{5}-98,56 \%, \mathrm{ChZT}_{\mathrm{Cr}}-95,25 \%$, zawiesiny ogólne $-97,45 \%$. Dla wskaźników eutroficznych osiągnięto niższe wyniki: azot ogólny - 70,69\%, fosfor ogólny - 93,93\%, z czego dla fosforu ogólnego nie osiągnięto wymaganego stopnia redukcji 130 razy na 998 próbek, a dla azotu 812 razy na 1007 próbek;

- przyczyną wysokich stężeń azotu ogólnego w ściekach surowych mogły być ścieki dowożone taborem asenizacyjnym, a to z kolei mogło wpłynąć niekorzystnie na proces usuwania azotu ze ścieków;

- pod względem eksploatacyjnym należy zwracać szczególną uwagę na ilość i skład ścieków dowożonych i wprowadzanych do oczyszczalni, tak aby nie dopuszczać do sytuacji w której następuje zaburzenie procesu oczyszczania ścieków;

- w dalszych badaniach należy przeprowadzić szczegółowe analizy dotyczące podatności ścieków surowych na rozkład biologiczny i na tej podstawie odpowiedzieć, czy były sprzyjające warunki do usuwania związków biogennych;

- podsumowując należy stwierdzić, że oczyszczalnia ścieków „Kujawy” pod względem zmniejszania podstawowych wskaźników zanieczyszczenia ścieków działa poprawnie, natomiast należy zwiększyć skuteczność usuwania azotu ogólnego.

\section{Literatura}

[1] Bever J., Stein A., Teichmann H.: Zaawansowane metody oczyszczania ścieków, Oficyna Wydawnicza Projprzem-EKO, Bydgoszcz 1997.

[2] Chmielowski K., Kurek K., Bąk K.: Efektywność oczyszczania ścieków na przykładzie oczyszczalni w Lipnicy Wielkiej. Infrastruktura i Ekologia Terenów Wiejskich 3/I/2012. Kraków, s. 213-224. 
[3] Chmielowski K., Satora S., Wałęga A.: Ocena niezawodności działania oczyszczalni ścieków dla gminy Tuchów. Infrastruktura i Ekologia Terenów Wiejskich 9/2009. Kraków, s. $63-72$.

[4] Hartmann L.: Biologiczne oczyszczanie ścieków, Wydawnictwo Instalator Polski, Warszawa, 1996.

[5] Krzanowski S., Wałęga A..: Ocena niezawodności działania mechaniczno-biologicznej oczyszczalni ścieków dla miasta Dąbrowa Tarnowska. Inżynieria włókiennicza i ochrona środowiska nr 14. ATH. Bielsko-Biała 2004.

[6] Pozwolenie wodno-prawne wydane przez wojewodę małopolskiego z dnia 25.02.2015 r. z mocą obowiązywania do dnia 31.12.2024 r.

[7] Rozporządzenie Ministra Środowiska z dnia 18 listopada 2014 r. w sprawie warunków, jakie należy spełnić przy wprowadzaniu ścieków do wód lub do ziemi, oraz w sprawie substancji szczególnie szkodliwych dla środowiska wodnego. Dz.U. 2014 poz. 1800.

[8] Sikorski M.: Charakterystyka ścieków wiejskich i sposób ich unieszkodliwiania. Wiadomości Melioracyjne i Łąkarskie nr 3, Częstochowa 1994.

[9] Sikorski M.: Oczyszczanie i oczyszczalnie w Polsce. Wiadomości Melioracyjne i Łąkarskie, nr 4, Częstochowa 1994.

[10] Sikorski M.: Przegląd procesów, metod i urządzeń do oczyszczania ścieków bytowogospodarczych możliwych do zastosowania w warunkach wiejskich. Zagadnienia Techniki Sanitarnej Wsi. Oczyszczanie ścieków wiejskich, procesy, urządzenia, eksploatacyjne. Wrocław 1989.

\section{ANALYSIS OF OPERATION EFFECTIVENESS OF THE "KUJAWY" SEWAGE TREATEMENT PLANT}

\section{S u m m a r y}

The paper presents the analysis of operation effectiveness of the "Kujawy" sewage treatment plant. It is a mechanical-biological treatment plant with increased removal of nutrients. This facility was designed for $251,818 \mathrm{PE}$ and average daily flow of $80,000 \mathrm{~m}^{3} \cdot \mathrm{d}^{-1}$. The biological process uses a three-phase biological reactor, in which the modified Bardenpho technology with low loading rates of activated sludge is carried out. The study covered the period from January 2009 to November 2014. The following pollutant indicators were analyzed in this study: $\mathrm{BOD}_{5}, \mathrm{COD}_{\mathrm{Cr}}$, total suspended solids, $\mathrm{N}_{\text {tot. }}, \mathrm{P}_{\text {tot. }}$. The degree of pollution reduction was calculated by taking into account the values of each indicator. Additionally, the reliability coefficient of the treatment plant was calculated for the analyzed sewage pollution indicators. Basic descriptive statistics were also calculated for the values of the examined indicators in raw sewage, treated sewage and for reduction of these indicators. Based on the collected and analyzed material it can be concluded that in terms of reduction of basic sewage pollution indicators, the operation effectiveness of the "Kujawy" sewage treatment plant is proper, however the efficiency of total nitrogen removal should be improved.

Keywords: domestic sewage, sewage treatment plant, treatment efficiency, reduction

Przestano do redakcji: 30.08 .2015 r.

Przyjęto do druku: 1.03.2016r.

DOI: $10.7862 /$ rb.2016.107 